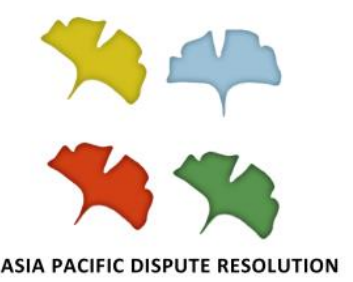

\title{
Human Rights Arguments in Trade Disputes: An Exploration of the Americas' Experience
}

\author{
Erika Cedillo \\ Peter A. Allard School of Law \\ University of British Columbia
}

\author{
APDR Working Paper Series \\ Volume 1 Number 1
}

ISSN 2371-6304

(c) (i) (9)

by Erika Cedillo, 2011.

This article is made available as part of the Asia Pacific Dispute Resolution

Working Paper Series and is licensed under a Creative Commons Attribution-NonCommercial-NoDerivatives 4.0 International License

(CC-BY-NC-ND) 



\title{
HUMAN RIGHTS ARGUMENTS IN TRADE DISPUTES: AN EXPLORATION OF THE AMERICAS' EXPERIENCE ${ }^{1}$
}

\author{
Erika Cedillo \\ Peter A. Allard School of Law \\ University of British Columbia
}

\section{Introduction}

Within the scholarly debate on the coordination between trade and human rights systems some argue that they should be left developing on their own, as has been the case in the past, while others advance the idea that they should be addressed jointly, coordinating their efforts in order to better advance their objectives. The Major Collaborative Research Initiative (MCRI) Project on "Asia Pacific Dispute Resolution: Understanding Coordinated Compliance with International Trade and Human Rights Standards in Comparative Perspective" aims precisely at understanding and advancing the coordination between trade and human rights. One objective of the broader Asia Pacific Dispute Resolution (APDR) project is to build knowledge on how disputes are solved across cultures. The APDR project "addresses the challenge of coordinating local compliance with international trade and human rights standards in the Asia-Pacific region." ${ }^{2}$ In order to build the knowledge on this specific region, the project analyzed the experiences in other regions on addressing human rights arguments in trade disputes.

The Americas is a region where constant efforts to integrate and improve trade have developed and it is the focus of this study as part of the comparative perspective needed for the APDR Project. By asking whether human rights arguments have been raised in trade disputes in the Americas' regional trade dispute settlement mechanisms, this paper looks at the experience in three major regional trade agreements in the Americas to bring to light if human rights arguments had been raised and how they have been addressed in trade related disputes. The decisions analyzed are from the dispute mechanisms of the

\footnotetext{
${ }^{1}$ I would like to acknowledge the generous support received from the APDR Project to write and present this paper at the Canadian Law and Society Association Annual Conference in New Brunswick in 2011.

${ }^{2}$ To learn more about the project see: Asia Pacific Dispute Resolution, online: <http://apdr.iar.ubc.ca/>.
} 
North America Free Trade Agreement (NAFTA), the Common Market of the South (Mercosur), and the Andean Community. ${ }^{3}$

The first purpose of the research was to report whether human rights arguments were raised, in any fashion, in the decisions from the dispute settlement mechanisms of these regional trade agreements. Additionally, the analysis moved to the consequences or the aftermath of some of those cases where human rights arguments were raised in the process of resolving a trade dispute. In the following pages, I start by contextualizing the scholarly debate about the relationship between trade and human rights law systems. I examine how, after having developed in parallel avenues, the importance of addressing them jointly has attracted the interest of many scholars for more than three decades. After this, I present the main characteristics of the trade agreements selected for this study. The three regional agreements, in a very general way, serve basically the same purposes of promoting free trade of goods and services among their members, despite some having a further objective of integration like the Andean Community. ${ }^{4}$ However, there are differences in the mechanisms for settling commercial disputes, which are explained further below.

Subsequent to the background review on the regional agreements and the debate on the relationship between trade and human rights law systems, I present the results from the systematic review done on the decisions taken by the dispute settlement mechanisms of the three international agreements. The methodology followed in this paper began with a review of the structure created by the regional agreement in order to identify the corresponding body and available information on the official website of each agreement. I identified the body in charge of settling disputes and reviewed the rules to be followed

\footnotetext{
${ }^{3}$ For the purpose of general reference to these agreements, these are called "regional agreements" throughout this paper. I use this terminology being aware that neither are all of them just free trade agreements, nor are they all full integration efforts.

${ }^{4}$ It is important to mention at this point there is a larger effort by the countries in the south of the continent to pursue a further integration in the so-called "Union of South American Nations (UNASUR)", which is inspired in the example of the European Union. The Constitutive Treaty of this Union entered into force, on March 11th, 2011, officially becoming a legal entity. The general purpose of this Union is "to build a South American identity and citizenship and to develop a political, economic, social, cultural, environmental, energetic, and of infrastructure, integrated regional space". See Tratado Constitutivo de la Unión de Naciones Suramericanas, online: UNASUR <www.pptunasur.com>.
} 
by the member states in the event that a trade dispute arises. Each regional agreement keeps a historical record of all the cases that have been presented before their dispute settlement body, regardless if there has been a change in the founding protocols of the agreement - like in the case of Mercosur. ${ }^{5}$ I obtained the decisions from the records that corresponded to the five-year period before this study: NAFTA and Mercosur 2005-09 and the Andean Community 2006-10.

The systematic review of the content of each decision that fell within the time frame of the study allowed me to understand the claim the parties were making, their position, the arguments from the deciding body and finally the decision that was reached. In this way, I identified the basis for human rights arguments in the trade dispute. For those cases in which human rights arguments were found, a special report format was filled out, following the APDR Project research protocol. The results of my review provide examples of the critical debate about the coordination of human rights and trade law systems at a practical level. The sections below, present how these mechanisms have dealt with trade disputes in which human rights arguments have been raised.

After looking at the question of whether human rights arguments have been raised or not and presenting the straight results from the research, some space is dedicated to analyze and comment on the implications and the aftermath of those cases where human rights arguments were raised by the conflicting parts or if the court/tribunal decided a trade dispute on human rights grounds. In the concluding part of this paper, I reflect on what might bring the future for the relationship between trade and human rights systems in the three regional agreements analyzed. The findings of this research on those trade cases with human rights arguments end up raising new questions for the debate on how the trade and human rights law systems can be better coordinated in practice.

\footnotetext{
5 The Dispute Settlement Mechanisms in Mercosur was originally regulated by Annex III of the Treaty of Asuncion, and then later by the Brasilia Protocol. Since 2004, it is regulated by the Olivos Protocol which created the Permanent Tribunal of Revision. See Solución de controversias, online: Mercosur <http://www.mercosur.int>.
} 


\section{A. Human Rights and Trade Law Systems}

Historically, trade and human rights systems have developed in parallel, but separately. However in the last two decades scholars have questioned this way of proceeding ${ }^{6}$ and therefore have advanced more and more the importance of exploring their relationship and finding ways of addressing them in conjunction. ${ }^{7}$ Authors such as Makau W. Mutua \& Robert L. Howse even suggest that "trade and investment agreements, as well as the practices of international business, must be held accountable to existing human rights law. Further, the spirit of human rights law must frame the development of trade law if either is to achieve its goals." 8 They recognize this objective poses big challenges for both systems, though. Nevertheless, they support the idea that at least trade rules should not violate human rights and should find ways to promote and protect them. Mutua \& Howse suggest that as long as trade rules respect the hierarchy of norms in international law by recognizing the erga omnes status of human rights law, this objective could be feasible.

The scholarly debate over the issue has had different approaches and nuances. A very illustrative example is the debate that occurred among Petersmann, Howse, and Alston on the approach from the first one on the so-called "constitutionalization of the WTO".9 Ernst-Ulrich Petersmann has advanced, on more than one occasion, the 'integration approach' according to which human rights should be integrated in the law of world-wide organizations like the WTO. Petersmann called attention to regional experiences in which this integrationist approach has linked economic integration and the protection of human rights. His two main examples are the European Union (EU) and the plans for a Free Trade Area of the Americas (FTAA) for which the protection of human rights is an

\footnotetext{
${ }^{6}$ Makau W. Mutua \& Robert L. Howse, "Protecting Human Rights in a Global Economy: Challenges for the World Trade Organization", in Hugo Stokke and Anne Tostensen, eds, Human Rights in Development Yearbook 1999/2000: The Millennium Edition (2001), online: SSRN <http://ssrn.com/abstract=1533544>, at 51 .

${ }^{7}$ Stephen Joseph Powell, "Small Steps: Ending Trade's Splendid Isolation from Human Rights" (2008), online: SSRN <http://ssrn.com/abstract=1115837>.

${ }^{8}$ Mutua \& Howse, supra note 6.

${ }^{9}$ Ernst-Ulrich Petersmann, "Time for a United Nations 'Global Compact' for Integrating Human Rights into the Law of World-Wide Organisations: Lessons from European Integration" (2002) 13:3 Euro J Int'l L 621 [Petersmann, "Global Compact"]; and Ernst-Ulrich Petersmann, "Taking Human Dignity, Poverty and Empowerment of Individuals More Seriously: Rejoinder to Alston” (2002) 13:4 Euro J Int'l L 845.
} 
essential element of the economic agreement. Petersmann argues the integration paradigm "should become accepted at the worldwide level in order to promote a new kind of global integration law based on human rights and the solidary sharing of the benefits and social adjustment costs of global integration." 10

In commenting on Petersmann article, Robert Howse, international trade law scholar, agrees that both topics are intertwined, recognizes that their relationship is a complex one, and, at a certain point, endorses the idea of having a higher level of human rights sensibility within the WTO regime. ${ }^{11}$ Nevertheless, Howse criticizes Petersmann for not specifying what he understands as "constitutionalism". For Howse, if Petersmann wants to further the integrationist approach of human rights and trade law he cannot leave the discussion only at the abstract level, he would need to get into the practical application of his model to assess its implications. One of the problems Howse identifies in the integrationist approach is that raising property and contract freedom to the level of human rights would raise questions as to how governments would justify their social interventions at the international level as limits to these "fundamental rights". As a consequence, for Howse, "Petersmann's notion that the substantive obligations of the WTO law (such as National Treatment) be understood as fundamental rights would make it more difficult than at present for WTO members to defend their public policies in terms of reasonable limits on those obligations." ${ }^{12}$ In Howse's reasoning this approach would give more deference to domestic regulations.

Philip Alston, international law scholar and human rights practitioner, also challenges Petersmann's approach and with a stronger tone. He recognizes how influential Petersmann's thoughts are given his experience and stature within international trade law scholarship. It is precisely for that reason he writes his reply with the aim of trying to prevent the readers from falling into Petersmann approach, which he considers "at best difficult to reconcile with international human rights law and at worst . . would

\footnotetext{
10 Petersmann, "Global Compact", supra note 9 at 623.

11 Robert Howse, "Human Rights in the WTO: Whose Rights, What Humanity? Comment on Petersmann" (2002) 13:3 Euro J Int'l L 651.

12 Ibid at 655 [emphasis in original].
} 
undermine it dramatically." 13 Alston argues for moving beyond analyses like Petersmann's and 'to engage in a systematic and intellectually open debate which acknowledges the underlying assumptions and meets a higher scholarly burden of proof than has so far been the case."14 Alston is aware of the importance of addressing the relationship between trade and human rights but calls for a careful consideration for their linkage. He groups Petermann's ideas into six propositions for which he gives further reasons on their problematic validity.

The relevance of their debate lies in how they show the complexities attached to addressing human rights and trade jointly. Both systems of law are grounded on premises of the highest importance for the nations of the world. Probably that is why they have evolved in isolation from one another. Nevertheless, those times of isolation need to end and countries need to find ways to make them coexist and provide solutions to those problems in which principles from both systems have a high priority but still one has to prevail over the other. We must not ignore the efforts that are being done. This paper addresses some examples on that. Still, no definite answers have been found and there are substantial challenges to overcome.

The relationship between trade and human rights and their implication for a country's development has been the central topic for a number of studies. A detailed example is David Kinley and Hai Thanh Nguyen's study on Viet Nam ${ }^{15}$ in which they recognize the connection between trade and human rights and the progress that this nation has made in terms of development after its accession to the WTO. At the same time, the authors made a thorough analysis of the implications and challenges that have come from this accession. In particular they expand on the effects it has had on human rights for the country's population and the many questions and challenges that remain open. They touch on topics such as the right to food, the rights of ethnic minorities, the rights of

\footnotetext{
${ }^{13}$ Philip Alston, "Resisting the Merger and Acquisition of Human Rights by Trade Law: A Reply to Petersmann" (2002) 13:4 Euro J Int'l L 815 at 816.

${ }^{14} \mathrm{Ibid}$ at 815.

15 David Kinley \& Hai Thanh Nguyen, "Viet Nam, Human Rights, and Trade: Implications of Viet Nam's Accession to the WTO" (2008) Sydney Law School Research Paper No. 08/30, online: SSRN $<$ http://ssrn.com/abstract=1105952>.
} 
children, labour and workplace rights, and human rights in the agricultural sector. All of these are involved in one way or another in trade issues.

Frank Garcia's 2003 study ${ }^{16}$ addresses the efforts that have been undertaken in the Americas to integrate human rights and democracy compromises into different trade agreements. He analyzed the cases of NAFTA, Mercosur, and the proposed Free Trade Area of the Americas (FTAA). Following the 'leverage model' 17 to address the relationship between integration systems and human rights protection in the region, Garcia asked if membership to these agreements have been used to leverage the protection of human rights and whether this kind of leverage should be part of the steps to be followed by the regional integration systems. He concluded that the linkage in the Americas' integration systems is more focused on trade and democracy; as if by attaining democratic governments would mean they are addressing human rights concerns. Another important finding from his research is that one of the decisive factors to achieve that linkage is related to political pressure from the United States or the European Union. Thus, his research shows the efforts from the integration systems in the region have not truly addressed general human rights. We could say it is an issue that still needs to be explicitly addressed in the integrationist efforts in the region, and not just as democracy but regarding human rights as a whole.

At the time of Garcia's study, there were major efforts for the consolidation of the FTAA. They have now faded and the FTAA is a proposal that has been frozen for some time. It could even be considered abandoned and with no future, especially because of opposition from governments such as Venezuela, Brazil, Argentina, and Bolivia. It is not the purpose of this paper to get into the details of the failure of the FTAA, ${ }^{18}$ but serves to highlight the efforts made for including democracy and human rights clauses, which were opposed mainly by the United States. If not in the clauses, they FTAA negotiating parties

\footnotetext{
${ }^{16}$ Frank J. Garcia, "Integrating Trade and Human Rights in the Americas", in Frederick M. Abbott, Christine Breining-Kaufmann \& Thomas Cottier, eds., International Trade and Human Rights: Foundations and Conceptual Issues (Ann Arbor: University of Michigan Press, 2003) 329, online: SSRN $<$ http://ssrn.com/abstract=470201>.

17 Garcia explains the leverage model as one which "involves making effective participation in extrinsic human rights systems a legal or political condition of integration system membership". See ibid at 329.

${ }^{18}$ For details see Garcia, supra note 16 at $343 \mathrm{ff}$.
} 
were trying to include them as part of the preamble of the treaty, which would not have been as effective as having them as a formal clause, but would have been better than not included at all. Garcia suggested effective participation in the Organization of American States (OAS) system as a way to strengthen the relationship between trade and human rights, but, he added, this would entail finding a way to make the United States accept the OAS system.

In the sections to follow, I present the results from the analysis done of the three major regional agreements in the Americas. In them, we find examples of this critical debate at a practical level and can be observed how these mechanisms have dealt with trade disputes in which human rights arguments have been raised.

\section{B. $\quad$ North America Free Trade Agreement (NAFTA)}

NAFTA was signed in 1993 and came into force in January 1994 for its three members: Canada, Mexico, and the United States. This agreement ${ }^{19}$ allocates three chapters to the dispute settlement mechanisms to be used among its members. Chapter 11, one of NAFTA's most relevant innovations at the time it was signed, is dedicated to disputes arising between an investor from one country against the government of another country for cases in which the investor party considers its rights have been violated by the host government. For these disputes, the investor alleging violations to investment obligations might have recourse to the World Bank's International Center for the Settlement of Investment Disputes (ICSID), ICSID's Additional Facility Rules, or the rules of the United Nations Commission for International Trade Law (UNCITRAL Rules). The additional facility applies when one of the parties to the dispute is not a signatory of the ICSID but for the dispute at hand accepts to submit it to the rules of the ICSID. In this case, Mexico is the only member of NAFTA who is not a signatory of the ICSID.

NAFTA Chapter 19 provides for the Review of Final Antidumping and Countervailing Duty Determinations, which is done by independent binational panels. The review is

\footnotetext{
${ }^{19}$ North America Free Trade Agreement, online: NAFTA <https://www.nafta-sec-alena.org/Home/Textsof-the-Agreement/North-American-Free-Trade-Agreement $>$ [NAFTA].
} 
started by a request to the Secretariat ${ }^{20}$ of NAFTA from an industry that considers itself affected by a determination from the investigating authority of a NAFTA party on imports from another NAFTA party. The decisions of binational panels are binding. The chapter also provides for a level of review for binational panels' decisions named the Extraordinary Challenge Committee procedure. This "is not an appeal of right but a safeguard to preserve the integrity of the panel process." 21 A party can resort to it if they consider a panel member has a serious conflict of interest in the dispute, the panel deviated from a rule of procedure, or exceeded its authority.

Finally, NAFTA Chapter 20 deals with disputes related to the interpretation or application of the treaty. This chapter establishes three levels for the resolution of a dispute. It starts by government to government consultations. If an agreement is not met within 30 days then a Party may submit the dispute to the NAFTA Free-Trade Commission. If no solution is raised at this stage within 30 days, then a consulting Party may call for the establishment of an arbitral tribunal.

For the purposes of the research involved in this paper, Chapter 11 investment disputes were not considered as the focus was completely directed to trade disputes, this means disputes regarding the imports and exports of goods and services. In addition, Chapter 11 procedures are done before an arbitral tribunal according to the rules selected by the parties. This implies that because arbitral procedures have the special feature of being confidential, the access to the decisions and statistics depend on the moment in which the governments of the Parties decide to make them public. Researchers have undertaken

\footnotetext{
${ }^{20}$ The Secretariat is the administrative body of NAFTA in charge of administering the trade dispute settlement procedures that arise under the treaty, and which supports the work of the Commission - the Commission is integrated by the Trade Ministers of the country members. The Secretariat is comprised of one national section in each country and provides support for the panels and/or tribunals that are conformed to settle disputes. Fernando Serrano Migallón, "El Capítulo XX: Disposiciones Institucionales y Procedimientos para la Solución de Controversias" (1993) 22 Serie I. Estudios de Derecho Económico Instituto de Investigaciones Jurídicas 271-290.

${ }^{21}$ NAFTA, supra note 19.
} 
important efforts to compile the disputes that have been solved pursuant to NAFTA Chapter $11,{ }^{22}$ but this depends on when the decisions become available to the public.

The procedures of interest for this paper are the disputes falling within NAFTA Chapters 19 and 20. There have been just three Chapter 20 cases that have reached the arbitral tribunal stage and none of them fall within the period determined for this study. Accordingly Chapter 20 cases are not included in the results reported. Tables 1 and 2 show the number of Chapter 19 decisions that were issued each year and the categories into which each fall, according to the status that NAFTA's Secretariat assigned to them. It is important to note that there can be more than one decision under the same file number. As the purpose of the research is to look into the arguments of the parties and the binational panels in any of their decisions, all the decisions that fall within the period of research selected were reviewed, regardless if there are more than one from each file number. The status that a decision can have accordingly is:

a) Active: a dispute that is still in process of being decided, usually expecting an answer from one of the parties to a decision issued by the binational panel.

b) Completed: a final decision has been issued by the binational panel and no further submissions are expected.

c) Terminated: this status is assigned to cases in which the binational panel either dismissed the complaint or the procedure has been abandoned by the parties and, given their lack of action, the binational panel decided to conclude it.

d) Extraordinary Challenge Committee: decisions issued according to the appealing mechanism provided for in NAFTA Chapter 19.

\footnotetext{
${ }^{22}$ See Scott Sinclair, "NAFTA Chapter 11 Investor-State Disputes (to October 1, 2010)", online: Canadian Centre for Policy Alternatives <www.policyalternatives.ca/publications/reports/nafta-chapter-11-investorstate-disputes-1>.
} 
Table 1

Number of decisions issued each year under NAFTA Chapter 19 procedure for trade disputes settlement

\begin{tabular}{|c|c|}
\hline Year & Number of decisions \\
\hline 2005 & 13 \\
\hline 2006 & 8 \\
\hline 2007 & 7 \\
\hline 2008 & 4 \\
\hline 2009 & 2 \\
\hline TOTAL & 34 \\
\hline
\end{tabular}

Table 2

Number of decisions per status assigned by the NAFTA Secretariat up to January 2010

\begin{tabular}{|c|c|}
\hline $\begin{array}{c}\text { Status of the case to which } \\
\text { the decision belongs }\end{array}$ & Number of decisions \\
\hline Active & 1 \\
\hline Completed & 25 \\
\hline $\begin{array}{c}\text { Extraordinary Challenge } \\
\text { Committee }\end{array}$ & 1 \\
\hline Terminated & 7 \\
\hline
\end{tabular}

In 34 decisions, no human rights arguments were raised. Within NAFTA, dispute resolution has been focused specifically on trade issues affecting the free movement of products among country members. This is a reflection of NAFTA's text in which human rights are not linked with trade in any of its provisions, except for some labour provisions in in its preamble. Many questions have been raised as to why NAFTA does not address 
human rights and follow the example of the European Union which addresses them together, recognizing their important linkage. The answers usually found are related to the reluctance from the United States to adopt multilateral human rights obligations. ${ }^{23}$ Smith even argues that it would not be until the United States commits to be subjected to multilateral human rights obligations that we would see a further development on the topic in this region.

The only part in which NAFTA can be seen related to human rights is through the two complementary agreements on labour and environmental cooperation. The North America Agreement on Labor Cooperation (NAALC) aims to enforce domestic labour standards and laws for providing better working conditions and living standards for workers in the region. ${ }^{24}$ To achieve these goals the parties have set eleven labour principles to which they have committed. The agreement provides a multi-level mechanism for dispute resolution to advance the enforcement of labour standards. The North America Agreement on Environmental Cooperation (NAAEC) was created to ensure that trade liberalization in the region "would be accompanied with effective cooperation and continuous improvement of the environmental protection provided by each country." ${ }^{25}$ This agreement also provides for a multi-level dispute settlement mechanism.

The two complementary agreements are the closest explicit linkage between trade and human rights that can be found within NAFTA's framework, thus the findings on the decisions reviewed do not come as a surprise. What might be surprising is that after 17 years of NAFTA and a continuous debate on the linkage between trade and human rights, the parties have not considered reevaluating this important topic to incorporate provisions that would look after enforcing human rights standards within the trade activities of its members. But for this to happen, an important step would be the United States accepting to submit itself to multilateral human rights commitments.

\footnotetext{
${ }^{23}$ James F. Smith, "NAFTA and Human Rights: A Necessary Linkage" (1994) 27:4 UC Davis L Rev 793.

${ }^{24}$ North American Agreement on Labor Cooperation, online: https://www.canada.ca/en/employmentsocial-development/services/labour-relations/international/agreements/naalc.html\#naalc

${ }^{25}$ The North American Agreement on Environmental Cooperation, online: Commission for Environmental Cooperation <www.cec.org $>$.
} 


\section{Mercado Común del Sur (Mercosur)}

The Common Market of the South (Mercosur) is a customs union established in 1991 through the Treaty of Asunción among Argentina, Brazil, Paraguay, and Uruguay. Its associate states are: Bolivia, Chile, Colombia, Peru, Ecuador, and Mexico. In 2006, Venezuela requested its accession to the union through a Protocol of Addition, but it has not been ratified by all members. Therefore, Venezuela's status is of an associate member, waiting to become a full member of the union. The main purposes of the Treaty of Asunción are:

the integration of the four state parties through the free movement of goods, services and productive factors; the establishment of a Common External Tariff (CET) and the adoption of a common trade policy; the coordination of macroeconomic and sectorial policies; and the harmonization of legislation in relevant areas. ${ }^{26}$

At the Presidents' Summit celebrated in 1994, the members approved the Protocol of Ouro Preto, which established the institutional structure of Mercosur and provided it with international legal personality. Mercosur covers a wide variety of topics that are addressed in its regulations such as trade and economy, productive integration, politics, social issues for economic development with social justice, family agriculture, science and technology, energetic cooperation, and human rights. For the purposes of advancing human rights in the region the supreme body of Mercosur, the Council of the Common Market (the Council) approved, in 2009, the creation of the "Institute for Public Policies on Human Rights." For Mercosur, the advancement of human rights represents a fundamental axis for its identity and development, as well as the basis of the integration process.

The system for dispute settlement in Mercosur was temporarily regulated by Annex III of the Treaty of Asunción and then by the Brasilia Protocol. According to Annex III any dispute would be submitted to the Group of the Common Market, the executive body of Mercosur, which would have 60 days to suggest recommendations for the resolution of the dispute. If a solution was not reached, the dispute would be brought before the

${ }^{26}$ Mercosur, online: <http://mercosur.int>. Website available in Spanish and Portuguese only. All translations done by the author. 
Council of the Common Market for the adoption of appropriate recommendations to settle the dispute. This system, which lasted less than a year, was replaced by another temporary system created by the Brasilia Protocol which lasted for 13 years. According to the Brasilia Protocol any dispute among the country members of Mercosur would be solved before an Ad Hoc Arbitral Tribunal.

In 2004, the members of Mercosur signed the Olivos Protocol to substitute the temporary system established by the Brasilia Protocol. According to the Olivos Protocol, disputes would first be addressed through direct negotiations. If these negotiations fail to reach a solution within 15 days, any of the parties can notify the Administrative Secretariat of Mercosur its intention to submit the dispute to arbitration before an Ad Hoc Arbitral Tribunal. ${ }^{27}$ The Olivos Protocol also created the "Permanent Tribunal of Revision" (TPR) which is the judicial organ of Mercosur. The TPR is empowered to review the arbitral awards issued by the Ad Hoc Arbitral Tribunals and to act as the first and final instance for resolving disputes, among other duties. The decisions from the Ad Hoc Arbitral Tribunals and the TPR are binding. In sum, the parties to a dispute within the Mercosur framework, after failing to settle their dispute through direct negotiations can opt to submit their dispute to an Ad Hoc Arbitral Tribunal or directly to the Permanent Tribunal of Revision. If the parties decide for the second option, the decision would be final and could not be subject of any further review as it is considered res judicata.

The number of Mercosur decisions from 2005 to 2009 is not as numerous as NAFTA decisions in the same period, as shown below in Tables 3 and 4. Nevertheless, they provide us with examples where human rights arguments have been raised by the parties. The tribunals made their decisions taking into account these arguments and giving their own reasoning on the matter being decided on human rights grounds. As explained in the outset of this section, and contrary to the case of NAFTA, Mercosur has included human rights as a fundamental basis of the agreement. Therefore, the members of the union can raise human rights arguments when contending a dispute.

\footnotetext{
${ }^{27}$ Further details on the dispute settlement procedures can be found in the Olivos Protocol, online: Mercosur <http://www.tprmercosur.org/es/docum/Protocolo_de_Olivos_es.pdf $>$.
} 


\section{Table 3}

Number of decisions per year regarding disputes among Mercosur members issued by Ad Hoc Arbitral Tribunals or the Permanent Tribunal of Revision, regardless of Protocol

followed

\begin{tabular}{|c|c|}
\hline Year & Number of decisions \\
\hline 2005 & 3 \\
\hline 2006 & 3 \\
\hline 2007 & 1 \\
\hline 2008 & 1 \\
\hline 2009 & 0 \\
\hline TOTAL & $\mathbf{8}$ \\
\hline
\end{tabular}

Table 4

Number of awards issued by each type of tribunal in the context of Mercosur according to the Protocol followed for its resolution

\begin{tabular}{|l|c|}
\hline \multicolumn{1}{|c|}{ Tribunal issuing the award } & $\begin{array}{c}\text { Number of } \\
\text { awards }\end{array}$ \\
\hline $\begin{array}{l}\text { Ad Hoc Arbitral Tribunal } \\
\text { (Brasilia Protocol) }\end{array}$ & 1 \\
\hline $\begin{array}{l}\text { Ad Hoc Arbitral Tribunal } \\
\text { (Olivos Protocol) }\end{array}$ & 2 \\
\hline $\begin{array}{l}\text { Permanent Tribunal of } \\
\text { Revision (Olivos Protocol) }\end{array}$ & 5 \\
\hline
\end{tabular}

In the context of Mercosur, there are two cases in which the parties have contended the case on human rights grounds: remolded tires and restriction of free movement. The first case was between Uruguay and Argentina on a ban imposed by Argentina on the import of remolded tires from Uruguay. The second is a well-known case, also between 
Argentina and Uruguay, on the failure of the Argentinean State to protect free movement. In particular, it focused on Argentina's failure to adopt appropriate measures to prevent and/or make end a restriction on free movement caused by protests cutting access to Argentinean territory via the international bridges of General San Martin and General Artigas. Some details of the disputes in these two cases are described in the subsections to follow, in particular the arguments raised by the parties and the decision from the tribunals. However, it is important to note beforehand that the second dispute was also brought to the International Court of Justice; this paper does not address those proceedings but remains within the context of Mercosur. ${ }^{28}$ The dispute escalated and the proceedings within Mercosur were just one part of the bigger dispute between Uruguay and Argentina; the dispute raised in Mercosur could have been an excuse from Uruguay to fight back Argentina by using the resources available pursuant to the Olivos Protocol. For the purpose of this study the proceedings started according to Mercosur's protocols suffice to provide an example of how human rights arguments are raised in trade disputes.

Referring back to the numbers showed in Tables 3 and 4, the majority of the decisions considered for this study (seven out of eight decisions) belong to either of these two cases-remolded tires and restriction of free movement. The remolded tires case takes five of the eight decisions from the Mercosur tribunals and the case on restriction of free movement comprises two of the eight decisions. After the dispute on free movement, there have not been any other disputes decided by Mercosur's tribunals. An issue that would be worthy of study is whether this is because there have been no other disputes among the parties, or because after the free movement dispute trust in the effectiveness of this tribunal for settling disputes among their members was lost. If there is a lack of trust, it may be derived from the lack of compliance from Argentina in the two major cases that

\footnotetext{
${ }^{28}$ The dispute brought before the International Court of Justice is named "Pulp Mills on the River Uruguay (Argentina v. Uruguay)". Argentina presented the case to the ICJ in May 2006, accusing Uruguay for violating the Uruguay River Statute by approving the construction and operation of pulp mills on the river. According to the Statute, the parties are responsible to consult with each other before any project is started that might modify the conditions of the river. Details on the decisions from the ICJ on this case can be found at Pulp Mills on the River Uruguay (Argentina v. Uruguay), online: International Court of Justice <www.icj-cij.org/en/list-of-all-cases>.
} 
the Tribunal of Revision has decided. These questions have to be kept in mind for the future development of dispute resolution in this region.

\section{Uruguay and Argentina on Remolded Tires ${ }^{29}$}

In December 2004, Uruguay requested the implementation of the Olivos Protocol dispute settlement mechanism against Argentina. Uruguay alleged that Act no. 25.626 ("the Act"), which imposed a ban on the import of remolded tires, put Argentina in breach of its obligations under Mercosur. As required by the Olivos Protocol, the parties went through direct negotiations but were unable to reach an agreement on the issue. On February 2005 Uruguay communicated to the Mercosur Secretariat its intention to start arbitration according to Chapter VI and subsequent chapters of the Olivos Protocol.

The dispute originated with an administrative decision issued by Argentina prohibiting the import of used tires; this was later extended by Act no. 25.626 prohibiting the import of remolded tires. Uruguay argued that by extending the prohibition to remolded tires Argentina was ignoring the differences between used and remolded tires. According to Uruguay, remolded tires do not generate transit security or environmental problems different from new tires and, therefore, should not be covered by the restrictions to free trade allowed for in article 50 of the Montevideo Treaty. ${ }^{30}$ Regarding the restriction to free trade based on protection to security (art. 50, b), Uruguay argued that remolded tires are safe. Regarding the restriction based on the protection of life and health of people, animals, and vegetables (art. 50, d) Uruguay argued that remolded tires are as durable as new tires, and therefore do not have a more serious environmental impact. In sum, Uruguay contended that Argentina violated articles 1 and 5 of the Treaty of Asunción by

29 The details of the case that are presented in this subsection are based on the content of Award from the Ad Hoc Arbitral Tribunal from October 25, 2005; Award from the Permanent Tribunal of Revision no. 1/2005 from December 20, 2005; Award from the Permanent Tribunal of Revision no. 1/2006 from January 13, 2006; Award from the Permanent Tribunal of Revision no. 1/2007 from June 8, 2007; and Award from the Permanent Tribunal of Revision no. 1/2008 from April 25, 2008. All available at Sistema de Solución de Controversias, online: Tribunal Permanente de Revisión <http://www.tprmercosur.org/es/sol_controversias.htm>.

30 The Treaty of Montevideo of 1980 precedes the Treaty of Asunción and is the agreement that creates the Latin American Integration Association (ALADI). It is the first declaration for the purpose of establishing gradually and progressively a Latin American common market. The parties to Mercosur recognized this treaty as a precedent for the Treaty of Asunción in its Annex I and continue to abide by its rules, which govern trade among its members. For further details on ALADI see: Asociación Latinoamericana de Integación, online: ALADI <www.aladi.org>. 
unduly prohibiting the free movement of goods within Mercosur, thereby violating Annex I of the Treaty of Asunción, principles of international law, and principles of integration law.

In its response, Argentina argued that the Act was a non-economic prohibition pursuant to the provisions of article 50 of the Treaty of Montevideo. Further, Argentina considered the Act as a preventive measure to avoid the potential damage that remolded tires could cause to the environment, health of the people, animals, and vegetables, in turn compromising the development of present and future generations. Argentina recognized and accepted the principles that promote free trade among Mercosur members, but argued that the Act was within the exceptions allowed by article 50 of the Treaty of Montevideo, giving three reasons for this. First, there was a legally protected interest in the life and health of people, animals, and vegetables. Second, the trade of remolded tires between Argentina and Uruguay was marginal and not significant based on the quantity of exports between the countries. Third, the principle of proportionality did not apply because the life, health, and quality of life of Argentina's inhabitants were at stake. Argentina made reference to other multilateral blocs which contain similar exceptions, such as the European Union, the International Health Organization, and the GATT-WTO. As well, it made reference to the precautionary principle in environmental law. ${ }^{31}$ Argentina contended that both principles of free trade and of environmental protection are equally part of the rules of Mercosur. Finally, it argued that the disputed act was exceptional, proportional, non-discriminatory, intended to protect one of the values mentioned in article 50 of the Treaty of Montevideo, and that there were no alternatives that would be less restrictive on intra-zone trade.

The Ad Hoc Arbitral Tribunal that heard the case decided by majority that the Argentinean Act was compatible with the Treaty of Asunción and its Annex I, with the derived rules of the Treaty, and with the applicable provisions of International Law. In its

\footnotetext{
${ }^{31}$ This principle is defined in article 15 of the Rio Declaration on Environment and Development of 1992: "Where there are threats of serious or irreversible damage, lack of full scientific certainty shall not be used as a reason for postponing cost-effective measures to prevent environmental degradation". See GA, Report of the United Nations Conference on Environment and Development, UN Doc A/CONF.151/26 (Vol. I) (1992).
} 
reasoning the Tribunal explained the two principles of free trade and environmental protection were in conflict and the precedence of one over the other needed to be decided. The Tribunal made reference to diverse instruments ${ }^{32}$ to affirm that environmental protection had become a priority issue among nations, including Mercosur. When addressing the issue of restriction to integration law, the Tribunal asserted that free trade cannot have absolute priority since it is an instrument of human wellbeing and not an end in itself. For the Arbitral Tribunal, cooperation and mutual support between economic and environmental policies are essential for the safe and sustainable development of the region. Regarding scientific evidence, the Tribunal considered incorporating "scientific uncertainty" as a necessary component of environmental policy because science is not always capable of offering the necessary evidence to compare-with certainty - the potential harms that different human activities might cause to the environment. Based on this reasoning, the Tribunal referred to the precautionary principle as corollary to the finding of scientific uncertainty and to the unquestionable need to implement environmental policies. Therefore, the Tribunal considered the precautionary principle as the authorization to adopt measures and prevent potential risks. In the view of the Tribunal, the import of remolded tires represented an acceleration of environmental liabilities for Argentina.

Uruguay appealed the decision before the Permanent Tribunal of Revision (TPR). In December 2005, the TPR decided to revoke the arbitral award. It determined that the Argentinean Act 25.626 was incompatible with the rules of Mercosur, as derived from a correct interpretation and legal application of the exceptions provided in article 50 of the Treaty of Montevideo. Therefore, the TPR ordered the revocation or modification of the Act and forbade Argentina to adopt or apply any action contrary to this statement or that would impede its implementation. Finally, the TPR determined that this decision would have effect until Mercosur adopted a consensual policy on the issue of implementation of remolded tires.

\footnotetext{
${ }^{32}$ Rio de Janeiro Declaration on Environment and Development, online: UNEP <www.unep.org>. The Framework Agreement on Environment of the Mercosur and Decisions no. 22/00 and 57/00 from the Council of the Common Market reaffirm the principle of free movement of goods in the regional territory and ratify the recognized exceptions: see Mercosur, supra note 29.
} 
For the TPR, in an integration scheme there are not two conflicting principles, there is only one principle - free trade - against which can be opposed certain exceptions-like the environmental exception relied on by Argentina. The matter of the case in the opinion of the TPR was the applicability of the environmental exception under the rules of Mercosur, not international law. For the TPR, the Ad Hoc Arbitral Tribunal failed to detail jurisprudentially the criteria required to call upon exceptions to the principle of free trade, nor did they analyze the case according to them. Given the absence of rules in the Mercosur for this purpose, the TPR established the criteria to be followed: analyze whether the measure is effectively restricting free trade, whether it is discriminatory or not, whether its application is justified, and whether it is proportional. According to these criteria, the TPR concluded the measure adopted by Argentina was restrictive of free trade, discriminatory, not justified, and disproportionate. Because this was the first case resolved by the TPR, to support its decision the Tribunal relied on case law criteria adopted by the Court of Justice of the European Communities (CJEC) (now Court of Justice of the European Union since December 2009). The TPR agreed with the criteria of the CJEC, especially when it came to the conclusion that domestic rules or practices cannot be considered acceptable according to the rules of the Treaty of the European Community if the health and life of the people can also be effectively protected with measures that do not restrict intra-community trade.

In its arguments, the TPR held that the prohibition was disproportionate and that it had not objectively reduced environmental damage. In addition, the TPR found that the damage was not severe or irreversible. Further, it held that trade cannot be restricted where a foreign product is as safe as products manufactured domestically but merely possibly less durable. For the TPR, the measure adopted by Argentina did not prevent environmental damage; in order to do that, the measures should be directed at limiting or eliminating used tires.

After this decision, three more opinions were issued by the TPR on this case. One resulted from an Argentinean request for clarifications, which was denied. A second decision was sought by Argentina against the countervailing measures (CVM) applied by 
Uruguay due to Argentina's failure to comply with the original decision. The TPR decided the CVM imposed by Uruguay were proportional and not excessive in relation to the consequences of Argentina's failure to comply. Finally, the last appeal was against Argentina for passing a new Act no. 26.329, which allowed the import of remolded tires but conditioned it on the previous export of used tires from Argentina. The TPR decided in April 2008 that the new Argentinean Act did not bring Argentina into compliance with Award 1/2005, and required Argentina to act upon it. The TPR determined Uruguay had the right to maintain the CVM in place until Argentina complied with the Award and dismissed Argentina's efforts to advance new environmental arguments grounded on a similar case on an import ban of remolded tires by Brazil decided by the Appellate Body of the WTO. ${ }^{33}$

It was important for the purposes of this paper to present, briefly summarized, the complete story of the proceedings on this dispute. This shows how the arguments on environmental protection and protection of life and health were considered by the Ad Hoc Arbitral Tribunal to take precedence over the right to trade. However, the TPR reversed this line of argument, placing trade as the fundamental objective of Mercosur to which all other principles must yield. It is startling if we consider that the members of Mercosur established human rights as the foundations of the Union. Would it mean that the Ad Hoc Arbitral Tribunal was more aligned to the purposes of Mercosur? If that is the case, should not that be the position from the TPR also? Up to now, Argentina continues to fail to comply with the decision of the TPR. This situation brings us back to the question of the effectiveness of the dispute settlement mechanism of Mercosur.

\section{Uruguay and Argentina on Restriction of Free Movement ${ }^{34}$}

As was explained in the outset, this dispute is just one part of a larger dispute between Argentina and Uruguay regarding the construction of pulp mills on the Uruguay's side of

\footnotetext{
${ }^{33}$ Brazil-Measures affecting imports of retreaded tires, WT/DS332/AB/R, online: WTO <www.wto.org>. In this case the Appellate Body decided the import ban imposed by Brazil was a "necessary" measure in terms of Article XX (b) of GATT.

${ }^{34}$ The details of the case that are presented in this subsection are based on the content of: Award of the Ad Hoc Arbitral Tribunal of September 2006 and Award of the Permanent Tribunal of Revision no. 2/2006. All available at Sistema de Solución de Controversias, supra note 29.
} 
River Uruguay. In 2006 Argentina brought Uruguay before the International Court of Justice (ICJ) for violations of the River Uruguay Statute, a treaty between the parties for the management of the river banks and the protection of the river. In the same year, Uruguay brought a dispute before the body of Mercosur on the failure of the Argentinean State to ensure free movement of goods between the two countries. Uruguay charged that Argentina was required to adopt appropriate measures to prevent or end the restriction to free movement caused by protests on Argentinean territory blocking the international bridges of General San Martín and General Artigas which connect the two countries. According to the Olivos Protocol, and after failed direct negotiations between the parties, an Ad Hoc Arbitral Tribunal was constituted for settling the dispute.

The origin of the dispute, as presented to the tribunal, were demonstrations engaged in by the population of Gualeguaychú on the Argentinean side of the River Uruguay. The demonstrations were in reaction to the construction of two privately-owned pulp mills on the Uruguayan bank of the river at Fray Bentos. The residents considered these mills as a future source of environmental pollution, and therefore a violation of the Agreement for the Administration of the River Uruguay between Argentina and Uruguay of 1975. The citizens created the group "Asamblea Ambiental Ciudadana de Gualguaychú" (Gualeguaychú Citizens' Environmental Assembly, AACG). Part of the protests organized by the AACG ended with the blocking of two international bridges connecting Argentina and Uruguay to put pressure on the governments to respond to their demands. Due to the roadblocks, the Argentinean General Directorate of Customs instructed customs to undertake an emergency operation to guarantee the normal flow of international trade, which involved guaranteeing alternative access routes and strengthening customs services on affected bridges. The roadblocks stopped two weeks after a speech from the Argentinean President in which he asked the protesters to lift the roadblocks.

Uruguay argued before the Ad Hoc Arbitral Tribunal that Argentinean authorities failed to take appropriate action to stop the roadblocks, though the number of demonstrators was, in general, very low. For Uruguay, Argentina's omissions up to that moment 
implied that in the event of new roadblocks, it would act in the same manner, hence generating a permanent state of doubt and insecurity.

According to Uruguay, the roadblocks caused serious damage and affected Uruguayan economic sectors and agents, mainly those related to imports, exports, tourism, and land transport of passengers and goods. Further, it argued that this situation was in violation of the principle of free movement of goods that is part of the fundamental principles of the common market established among the members of the Mercosur by the Treaties of Asunción and Montevideo. As for the free movement of people, the roadblocks disregarded the current commitments among the parties under international human rights instruments. In its claim, Uruguay referred to other agreements related to the issue such as the Agreement on International Ground Transportation and the rules from the WTO. Uruguay also brought up a similar case decided by the Court of Justice of the European Communities, Commission v France, by which the court held France responsible for the roadblocks made by some civilians. ${ }^{35}$

In its answer, Argentina argued that Uruguay had innovated and expanded the matter of the dispute from the direct negotiations phase, and asserted that the claim was devoid of purpose because by the date of the demand, the roadblocks had ceased and had not happened again. In addition, Argentina qualified the claim as nonspecific and abstract because it required Argentina to take action in case these kind of protests happened again, without specifying which measures should be adopted.

Argentina further claimed that the roadblocks did not damage the trade and tourism between these two countries. On the contrary, during the roadblocks both activities increased. Argentina also asserted that the protests represented the exercise of a legitimate right. Therefore, this situation constituted the juxtaposition of two rights. On one hand, the rights to free speech and assembly, and the right to free movement of goods on the other. For Argentina, the international laws of human rights have constitutional status while the laws of integration have the status of regular laws. Regarding the free movement of people that Uruguay alleged was damaged by the roadblocks, Argentina

${ }^{35}$ Commission v France (1997), Case C265/95 (Eur Ct J). 
answered it was not yet operational in the context of Mercosur as it is in the European Union. Equally, the right to free movement as may affect the transport of goods to or from third countries was not yet valid in Mercosur's process of regional integration.

Argentina grounded its opinion on the idea that human rights could justify a restriction on the exercise of the rights established in an integration treaty. To support this, Argentina brought up the case Schmidberger decided by the Court of Justice of the European Communities, which gives priority to the right of free speech over the free movement of goods. For Argentina, it had to be recognized that freedom of speech, freedom of assembly, and the right to protest have special relevance among human rights; to which the right to choose the public space where the protest can be exercised with more efficacy should be added. Following this reasoning, Argentina considered that opening the bridges would have entailed an unacceptable repression by the standards of Argentinean public law.

Consequently, for Argentina dissuasion was the only legitimate course of action open to the government.

Argentina also emphasized that the movement of goods and people between the two countries always had alternative access routes. Furthermore, Customs and Immigration services were reinforced during the protests. These actions showed, according to Argentina, that there were no omissions from them.

The Ad Hoc Arbitral Tribunal unanimously declared that the absence of due diligence on the part of Argentina to prevent or cease the bridge blockages was not compatible with the commitment of the State parties to guarantee the free movement of goods and services among their territories pursuant to Mercosur foundational treaty. Finally, the Tribunal decided it was not justified in law for the Tribunal to make decisions over future actions from Argentina.

Regarding the failure by omission pursuant to Mercosur legislation, the Tribunal concluded that Argentina violated the free movement principle that article 1 of the Treaty of Asunción considers as a core commitment among member states. The effects of the 
citizens' right to protest exceeded the limits of respect that the States owe to the legislation compelling them to guarantee the free movement of goods and services. For the Tribunal, Argentina failed to prove that it could not have adopted other actions to deter the protesters without violating their basic rights.

For the Tribunal, Argentina seemed to condition its international commitment assumed in the Treaty of Asunción to the legal possibilities that their national law allows in Human Rights matters, which goes against the principle that States cannot evade their international commitments invoking rules of domestic law (art. 27 Vienna Convention on Treaty Law of 1969). The Tribunal argued that the Argentinean Constitution and the international treaties on Human Rights recognize the relativity of subjective rights before the subjective rights of others and the possibility of their limitation for reasons of general wellbeing. Therefore, the Tribunal concluded that not even in Argentinean Law is the right to protest absolute and that it must be limited when it affects the rights of others. Accordingly, the Tribunal referenced the Universal Declaration of Human Rights, the American Convention on Human Rights (Pact of San José, Costa Rica), the International Covenant on Civil and Political Rights; all of which had been part of the Argentinean Constitution since they were incorporated to it in 1994.

Argentina did not appeal the decision; however, the roadblocks were re-established on one of the routes and the conflict continued. The decision from the ICJ was issued on April 2010, determining Uruguay failed to comply with the consultations on the pulp mills projects with Argentina, pursuant to the Statute on Uruguay River of 1975. However, the ICJ held that Uruguay did not violate other substantial obligations of the agreement. Finally, the ICJ found that Argentina had not proven environmental, visual, or sound contamination. ${ }^{36}$ After this decision, the presidents of both countries held meetings to finally reach an agreement on the dispute. The roadblocks were finally lifted

\footnotetext{
36 “Uruguay's and Argentina Celebrate Court's Ruling on Pulp Mill Dispute”, MercoPress (April 20th, 2010), online: MercoPress <http://en.mercopress.com/2010/04/20/uruguay-s-and-argentina-celebrate-courts-ruling-on-pulp-mill-dispute>.
} 
on June 19, 2010, but not without declarations from protesters that they would continue their fight if they did not see the solutions they expected. ${ }^{37}$

The aftermath of the decision suggests that the initiation of the proceeding according to Mercosur's mechanism was merely Uruguay trying to divert attention from the main conflict that was being addressed by the International Court of Justice. The decision from the TPR, by not having further impact, might also be seen as undermining the effectiveness of the dispute settlement mechanisms of Mercosur. On the issue of human rights, this dispute was argued on grounds of human rights compliance. However, once more, the Tribunal gave priority to the international commitment adopted by Argentina on the free movement of goods and people and recognized it as a core commitment among Mercosur members. Human rights were again secondary to trade principles.

\section{Andean Community (CAN)}

The Andean Community includes Bolivia, Colombia, Ecuador, and Peru. ${ }^{38}$ These countries agreed to cooperate for the "purpose of achieving a more rapid, better balanced, and more autonomous development through Andean, South American, and Latin American Integration." 39 Its associate countries are Chile, Argentina, Brazil, Paraguay, and Uruguay, while Mexico and Panama are observers. The supreme organ of the Andean System of Integration is the Presidential Andean Council, integrated by the chiefs of state of the member states of the CAN. The integration process started with the signing of the Cartagena Agreement in 1969. This union was known as the Andean Pact until 1996. In 1997, the parties amended the Cartagena Agreement, through the Trujillo Protocol, to give birth to the Andean Community.

\footnotetext{
${ }^{37}$ Camila Navarrete, "Argentinos levantan bloqueo de puente con Uruguay iniciado hace tres años", biobiochilecl (June 19, 2010), online: biobiochile.cl <http://www.biobiochile.cl/2010/06/19/argentinoslevantan-bloqueo-de-puente-con-uruguay-iniciado-hace-tres-anos.shtml $>$.

${ }^{38}$ Chile was a member but withdrew from the Pact during the Pinochet regime. Venezuela was also a member but announced its withdrawal in 2006.

${ }^{39}$ Quiénes somos, online: Andean Community

$<$ http://www.comunidadandina.org/Seccion.aspx?id=189\&tipo=QU\&title=somos-comunidad-andina $>$.
} 
The structure of the CAN comprises a large number of organizations, committees, and institutions that have been created to support the integration process. ${ }^{40}$ They address a wide array of topics such as economy, trade, health, labour, business, education, food, social agendas, intellectual property, international relations, democracy, and human rights, among many others. As part of the commitment of its members to democracy, in 1998 the Andean Council of Foreign Ministers elaborated an Additional Protocol to the Cartagena Agreement entitled the "Andean Community Commitment to Democracy."41 This Protocol establishes as an essential condition for political cooperation and integration the full observance of democratic institutions and the rule of law. Regarding human rights, the members of the Andean Community have made declarations recognizing respect for human rights - political, economic, and social — as a fundamental norm for the conduct of the member states and their defense is an international obligation they have committed to. All of the members of CAN are signatories to most international instruments for the protection of human rights. In 2002, the members of the CAN adopted the "Andean Letter for the Promotion and Protection of Human Rights" to ensure the observance of human rights, to strengthen democracy and the rule of law, and to further the entrenchment of a culture of peace in the Andean nations. For these purposes, since 2004, the member states have developed a schedule for the promotion and execution of the Andean Letter on Human Rights. ${ }^{42}$ From the above, we can observe a very prominent role given to human rights by the members of the Andean Community for the accomplishment of their overall goals. Additionally, as Garcia pointed out, in this region, as well as in Mercosur, the protection of human rights is deeply linked to democratic forms of government. ${ }^{43}$

Regarding dispute resolution and as part of the integration process, the members of the Andean Community created, in 1979, the Andean Court of Justice as the judicial body of

\footnotetext{
${ }^{40}$ For details of the structure of the CAN and the topics in which it acts see Comunidad Andina, online: Comunidad Andina <www.comunidadandina.org>.

41 Democracy and Human Rights online: Comunidad Andina <www.comunidadandina.org/exterior/democracia.htm>.

${ }^{42}$ Decisión 586: Programa de Trabajo para la Difusión y Ejecución de la Carta Andina para la Promoción y Protección de los Derechos Humanos, online: Sistema de Información sobre Comercio Exterior <http://www.sice.oas.org/trade/junac/decisiones/DEC586s.asp>.

${ }^{43}$ Garcia, supra note 16.
} 
the Andean Community. It is comprised of four judges representing each member. Its spheres of competence include:

- Nullity Actions,

- Actions for Non-Compliance,

- Appeals for Omission or Inaction,

- Arbitration,

- Labor Actions, and

- Interpretation of the rules comprising the legal system of the Andean Community.

Table 5

Number of decisions from the Andean Court of Justice published from 2006-2010 (up to July) ${ }^{44}$

\begin{tabular}{|l|c|}
\hline \multicolumn{1}{|c|}{ Type of Action } & $\begin{array}{c}\text { Number of decisions } \\
\text { published }\end{array}$ \\
\hline Nullity Actions & 5 \\
\hline Actions for Non-Compliance & 56 \\
\hline $\begin{array}{l}\text { Appeals for Omission or } \\
\text { Inaction }\end{array}$ & 4 \\
\hline Labor Actions & 2 \\
\hline Preliminary interpretations & 735 \\
\hline
\end{tabular}

${ }^{44}$ It is important to note the number of decisions reviewed does not represent the number of different cases, there might be more than one decision belonging to the same case. 
The level of activity in the Andean Court of Justice is significantly higher compared to NAFTA and Mercosur, but it is important to note that it has also been operating for longer. In Table 5 we can see the number of decisions that have been issued according to the jurisdiction provided to the Court by its creation Protocol. The period of review for the Andean Court's decisions is 2006-10. It calls attention to the fact that despite arbitration being one of its functions, there have not been, in the history of the Court, any arbitral proceedings. For the purposes of this study the three categories of interest are nullity actions, actions for non-compliance, and appeals for omission or inaction. Table 6 details the number of decisions published per year, per category. These three categories were thoroughly reviewed for human rights arguments. In four cases among the Actions for Non-Compliance the Court motivated its decision on human rights grounds. In the subsections ahead will be given some details on these cases to provide an overview of the type of arguments that were debated in these disputes.

\section{Table 6}

Distribution of decisions issued per year of study for the three categories of interest for the present study

\begin{tabular}{|l|c|c|}
\hline \multicolumn{1}{|c|}{ Type of decision } & $\begin{array}{c}\text { Year of } \\
\text { publication }\end{array}$ & $\begin{array}{c}\text { Number of } \\
\text { decisions }\end{array}$ \\
\hline Nullity Actions & 2007 & 3 \\
\hline & 2009 & 1 \\
\hline & 2010 & 1 \\
\hline Actions for Non-Compliance & 2006 & 32 \\
\hline & 2007 & 9 \\
\hline & 2008 & 7 \\
\hline & 2009 & 2 \\
\hline & 2010 & 6 \\
\hline $\begin{array}{l}\text { Appeals for Omission or } \\
\text { Inaction }\end{array}$ & 2007 & 4 \\
\hline
\end{tabular}


Regarding the actions for non-compliance, according to articles 23 to 27 of the Treaty Creating the Court of Justice of the Andean Community, ${ }^{45}$ an action can be started by the General Secretariat, the member States or affected individuals, provided that all requirements are met. The main requirement is to complete the preliminary administrative procedure before the General Secretariat. This procedure requires a report to a member state that is alleged to have failed to comply with its obligations pursuant to regulations of the Andean Community. The General Secretariat would then issue an informed opinion regarding the compliance, or lack thereof, with such obligations. If the opinion is of non-compliance, and the member state does not take actions to comply, the General Secretariat will require the Court to decide on the subject matter. The cases which are presented below all went through this preliminary procedure, with the involved member state resisting compliance with Andean regulations, in order to be brought before the Andean Court of Justice.

\section{Farmer-Importer-User program - Farmagro S.A., et al v. Republic of Peru ${ }^{46}$}

In this dispute, Farmagro, S.A. and its co-actors ${ }^{47}$ filed an action for non-compliance against the Republic of Peru for the breach of diverse articles of the Agreement Establishing the Andean Court of Justice, of Decision 436 of the Commission of the Andean Community, ${ }^{48}$ and of the Technical Handbook for the Register and Control of Chemical Pesticides for Agricultural Use. The dispute was started because Peru created the designation Farmer-Importer-User (FIU, or AIU in Spanish) by issuing two resolutions and two decrees that established the Farmer-Importer-User Register. These Peruvian regulations established a mechanism for the import of pesticides for personal agricultural use. It consists of a special register for farmers who want to import those

${ }^{45}$ Treaty for the Creation of the Court of Justice of the Andean Community (Doc. Básico 2 Codificacion del Tratado de Creación del Tribunal de Justicia de la Comunidad Andina), online: Comunidad AndinaDocumentos Oficiales, <http://www.comunidadandina.org/Documentos.aspx>.

${ }^{46}$ Farmagro, et al v. Republic of Peru (Jan. 27, 2009), file number 05-AI-2008, online: Comunidad Andina - Documentos Oficiales - Procesos del Tribunal de Justicia <http://intranet.comunidadandina.org/IDocumentos/c_Newdocs.asp?GruDoc=11>.

47 The actors for this action are: Farmagro S.A., Bayer S.A., Basf Peruana S.A., Productos Químicos Peruanos S.A., Farmex, S.A., San Miguel Industrial S.A., Tecnología Química y Comercio, S.A., Servicios y Formulaciones Industriales S.A. and SYNGENTA CROP Protección S.A.

48 Decision 436 issued in 1998 established the Andean Rule for the Register and Control of Chemical Pesticides for Agricultural Use which came into effect when the Andean Technical Handbook for the Register and Control of Chemical Pesticides for Agricultural Use was published in 2002. 
kinds of pesticides for their personal use, provided that it is done within the strictly required parameters. The plaintiffs argued the measures adopted by Peru established a different treatment for the FIUs. These measures provided a more favourable regime for the register and control of chemical pesticides for agricultural use, and, as a consequence, allowed FIUs to import pesticides without fulfilling the requirements established by Andean rules. The claimants argued that this special regime could cause several consequences that could have serious impacts on human health.

Peru argued that it was applying the principle of "indispensable complement" to legislate on the issue. ${ }^{49}$ At the same time it argued that according to an interpretation of Decision 436 , the national registration number of pesticides -issued by the designated national authority of each Andean member, is only for people who commercialize those products. Therefore, the Decision 436 does not apply to FIUs because they acquire the pesticides for their own use and in quantities needed to satisfy their requirements. Additionally, Peru argued that the pesticides imported under FIU meet the security measures for their use and handling. The General Secretariat of the Andean Community, as part of the preliminary procedure, issued its Opinion no. 03-2007 finding the Republic of Peru to have failed to meet their Andean obligations when creating the FIU Register.

The Andean Court declared Peru to be in breach of the regulations stated in the demand by continuing the FIU program; ordered Peru to rescind the regulations governing it and all the registers granted; and ordered it to refrain from adopting measures conflicting with Andean Community Law. In its reasoning, the Court explained the protection of rights of first order like life, health, and to enjoy a healthy environment are the guidelines followed by Decision 436. For the Court, the second objective mentioned in the regulation, clearly reflects the specific intention of Community legislators: to protect life, health and the environment; and to achieve food safety in the sub-region, increase levels of agricultural productivity, substitute agricultural imports, and increase exports. The Court called attention to the wording of Decision 436 where it mentions a harmonized system for the

49 According to this principle, the members of the Andean Community cannot legislate on matters regulated by Andean norms, except when it is necessary for the correct execution of the Andean norms. See: Andean Court of Justice, Prejudicial Interpretation issued 25 February 2010 in the process number 115-IP-2009, published in the Official Gazette of the Cartagena Agreement no. 1828, 30 April 2010. 
register and control of pesticides for agricultural use contributes to improve production, commercialization, use, and final disposition of waste in the country members, improving quality, efficiency, and security for human health and the environment. For the Court, these arguments, and the whole Decision 436 evidence that the basis for having a harmonized system for the register and control of pesticides is the protection of life, health, and the environment, and that this purpose goes beyond the regulation of trade and the formal harmonization of the control and register of pesticides.

Continuing with its decision, the Court found that in order to achieve an adequate standard of living, it is imperative to respect human rights, including the rights to life and health. The Court made reference to other decisions where it has taken the protection of human rights as the foundation for an appropriate interpretation of Andean rules. The Court referred to the interpretation it made of Decision 197 of the Commission of the Cartagena Agreement where it held that "further than business purposes of efficiency and productivity argued in the Decision, Andean legislation should be interpreted in the light of Human Rights protection because entrepreneurial freedom shall develop within the framework of human rights and fundamental rights, therefore, it is not an absolute right without limits." ${ }^{50}$ Consequently, the Court rejected the argument from Peru that the pesticides register is only applicable for the imports with commercial purposes.

Finally, the Court affirmed that when the right to competitive agricultural development is faced with the rights of life, health, and access to a safe environment, it is clear that the former has to yield to the latter. The Court concluded the FIU program goes against Decision 436, finding that it was clearly discriminatory and contrary to the fundamental right of equality because there is not sufficient reason to establish a more favorable and flexible treatment for FIUs.

According to media reports, the Peruvian government did not welcome the decision. In fact, the Minister of Agriculture declared at an event with agricultural exporters that the

${ }^{50}$ Farmagro, et al v. Republic of Peru, supra note 46, at 23. [emphasis added]. 
government was going to put the decision of the Court on hold. ${ }^{51}$ The president and vicepresident complained that the Court decided in favor of 8 laboratories and against over 400 exporters that generate over 140 thousand jobs. Regarding the proceedings, another action for non-compliance was filed by the plaintiffs on December 2010 before the Court. The Court, once again, declared Peru in breach of Andean regulations and called for compliance.

\section{Salt - General Secretariat of the Andean Community v. Republic of Ecuador. ${ }^{52}$}

This action was started by the General Secretariat against Ecuador for the alleged breach of diverse articles of the Agreement Establishing the Andean Court of Justice, the Cartagena Agreement, and Resolution 897 of the General Secretariat. The Government of Colombia presented a claim to the General Secretariat regarding Resolution 274 from COMEXI (Ecuadorian Council of Foreign Trade and Investment) which suspended imports of salt into Ecuador. The General Secretariat investigation ended with Resolution 897 where Ecuador's salt imports suspension was qualified as a restriction of intrasubregional trade and required Ecuador to lift COMEXI's Resolution 274. In response, COMEXI issued Resolution 368 suspending salt imports conditionally and for two years. During this time, COMEXI required the elaboration of a control procedure to guarantee the safety of salt imports for human consumption, applicable also for national production. Based on complaints from Peru and Colombia and information obtained by the General Secretariat, the latter issued Opinion 05-2007 by which it found Ecuador in flagrant and continued failure to comply with Andean legislation because of the measures it adopted and the ones it refused to suspend.

Ecuador argued in its answer that the decisions adopted by COMEXI are founded on Andean legislation and on the rules of the Agreement on Sanitary and Phytosanitary

\footnotetext{
51 "Ministro de Agricultura anuncia dejarán en suspenso fallo de la CAN sobre regimen Agricultor Importador Usuario" (April 19, 2010), online: AgroNegocios Perú <http://www.agronegociosperu.org/noticias/190410_n2.htm>; Yimmy Beltrán, "Agroexportaciones podrían crecer si se aprovechan beneficios de los TLC" Aeronoticias (April 17, 2010), online: Aeronoticias <http://www.aeronoticias.com.pe>.

52 General Secretariat of the Andean Community v. Republic of Ecuador (July 15, 2009), file number 05AI-2007, online: Comunidad Andina - Documentos Oficiales - Procesos del Tribunal de Justicia $<$ http://intranet.comunidadandina.org/IDocumentos/c_Newdocs.asp?GruDoc=11>.
} 
Measures from the WTO and the Codex Alimentarius because they privilege the right to health above any commercial interest. Moreover, Ecuador argued that the measures adopted have been effective for reducing the consumption of salt without iodine, and comply with the principles of proportionality, causality, and irreplaceability. Further, it was argued that the measures are non-discriminatory because they are general and there is not any other control measure that the country could have adopted for protecting public health. The measures were aimed at controlling the entrance of salt products that could be harmful for the health of Ecuadorians.

The Court found Ecuador in breach of Andean regulations and required it to adopt necessary measures to end the infringement and, therefore, reverse the restrictions on salt imports. Regarding the argument on the measures being in protection of public health, the Court concluded the evidence and arguments presented during the proceeding showed that Ecuador breached Andean legislation repetitively and continuously. Ecuador failed to adopt appropriate measures to solve the underlying problem, and therefore failed to meet its obligations to the Andean Community.

After this decision, there was a request for clarification and extension filed by the third party interveners. ${ }^{53}$ The Court overruled the requests and added a final addendum to its decision for clarification of the purpose of the action started in this case. The Court reasserted that the serious impact on public health due to the lack of iodine in the imported salt cannot be argued as a defense to the responsibility of a member State not to breach the Andean rules. These reasons can only be the basis to claim the nullity of a rule but cannot be raised in an action for non-compliance in which the objective failure of the state to meet the Community rule is reviewed.

\footnotetext{
${ }^{53}$ These were representatives of several Ecuadorian communities who supported the measures adopted by the Ecuadorian government as a way to control the entrance of salt they considered harmful for Ecuadorians' health.
} 
According to media reports, Ecuador decided to comply with the decision from the Court by adopting diverse measures to lift the restrictions on salt imports and some others aimed at controlling and supervising the quality of the product. ${ }^{54}$

\section{Slot machines - Game Technology Ltda. v. Republic of Ecuador. ${ }^{55}$}

The action was file by the Inter-American Society Game Technology Ltda. (Game Technology) against Ecuador for the alleged breach of diverse articles of the Agreement Establishing the Andean Court of Justice, of the Cartagena Agreement, of Decisions $439^{56}$ and $510^{57}$ of the Andean Commission, and of the General Agreement on Trade and Services (GATS). Game Technology is a Colombian company dedicated to providing services of renting or exploiting slot machines, games for casinos, and game rooms. The company is part of the Program for the Liberalization of Trade in Services of the Andean Community. The dispute has its origins in three decrees (Decrees 3400, 1186, and 355) issued by Ecuador to regulate the use of slot machines. ${ }^{58}$ According to Game Technology these decrees violated Andean legislation because they established a barrier to the entrance of gambling services and slot machines. The limitations were disproportionate because they did not guarantee public morality or prevent gambling problems. Additionally, the company argued the decrees privileged suppliers of game rooms and went against suppliers of electronic slot machine rooms.

For Game Technology, taking into consideration the rules from the WTO regarding the similarity of services, it was evident the activities of casinos and game rooms are direct

\footnotetext{
54 "Ecuador libera el ingreso de sal de mesa extranjera," Expresso.ec (November 7, 2009), online: expresso.ec <www.diario-expreso.com>; "COMEXI acogerá resoluciones de la CAN para importación de sal de mesa" (15 December 2009), online: EcuadorInmediato <http://www.ecuadorinmediato.com/index.php?module=Noticias\&func=news_user_view\&id=118344>.

${ }_{55}$ Inter-American Society Game Technology v. Republic of Ecuador (Jan. 23, 2008), file number 03-AI2006, online: Comunidad Andina - Documentos Oficiales - Procesos del Tribunal de Justicia <http://intranet.comunidadandina.org/IDocumentos/c_Newdocs.asp?GruDoc=11>.

${ }^{56}$ Decision 439 of the Commission establishes the General Framework of Principles and Norms for Trade Liberalization of Services in the Andean Community. Available online: Sistema de Información sobre Comercio Exterior 〈http://www.sice.oas.org/trade/junac/decisiones/dec439s.asp>.

${ }^{57}$ Decision 510 of the Commission establishes the Adoption of the Inventory of Restrictive Measures for Trade in Services. Available online: Sistema de Información Sobre Comercio Exterior <http://www.sice.oas.org/Trade/Junac/decisiones/DEC510s.asp>.

${ }^{58}$ Decree 3400 is the General Regulation of Touristic Activities, Decree 1186 is the General Regulation for the Application of the Ecuadorean Tourism Act, and Decree 355 amended these two regulations on the matter of slot machines.
} 
competitors. Therefore, the services should be treated equally, without discrimination. Otherwise, they would be violating Andean legislation and the multilateral norms of the WTO.

Ecuador argued it was not violating Andean legislation because the measures adopted did not restrict access to the gambling services market. Moreover, the measures adopted were equally applied to nationals and foreigners, therefore Game Technology was not being discriminated against. One of Ecuador's main arguments was that the measures adopted regarding slot machines were aimed at protecting morality and preserving public order and the lives and health of people, and that Andean legislation authorizes the member states to legislate with these aims. Given the damages that gambling can cause, it was argued that each State can decide how to regulate and restrict gambling activities, especially slot machines.

The Andean Court decided against the claimants. The Court reasoned that considering the type of game (slot machines) and its impact upon gambling habits, countries can adopt measures for their control, such as different regulations and warnings. The Court concluded that the measures were necessary to protect health and public order (supplemented with other regulations). The Court recognized that Ecuador was not absolutely prohibiting slot machines, but restricting their operation to casinos in hotels as a measure to control access to the machines by minors. The Court found that these measures were commensurate with the aims pursued.

For the Court, the measures adopted were not protectionist. Moreover, the Court found them to be in accordance with the Andean legislation that allows country members to issue measures in regards to liberalization of services, keeping in mind that one of the main objectives of the Cartagena Agreement is to improve the standard of living of the Community's population. Therefore, the Court dismissed the complaint. There was a request from Ecuador for extension and explanation of the judgement but the Court overruled the request and there have been no further actions related to this case. 


\section{Test data - Association of Colombian Pharmaceuticals (ASINFAR) v. Republic of Colombia ${ }^{59}$}

In this case, the Association of Colombian Pharmaceuticals (ASINFAR) filed an action of non-compliance against Colombia for issuing Decree 2085 in alleged violation of diverse articles of the Agreement Establishing the Andean Court of Justice and of Decision 486 of the Commission of the Andean Community. ${ }^{60}$ On September 19, 2002 the government of Colombia issued Decree 2085 to regulate the information provided to obtain a sanitary registration for new chemical entities in the pharmaceutical sector. The decree protected undisclosed information (test data) presented for the purpose of obtaining the sanitary registration for new drugs by authorizing periods of exclusivity for the recipient of the registration. Decree 2085 was enforced by the Colombian National Institute for Monitoring Drugs and Foods (INVIMA by its initials in Spanish).

The petitioner, ASINFAR, argued that by issuing this decree the Colombian government was regulating beyond its competence and was violating Andean legislation. Moreover, the Association alleged the protection given to this information carried harmful consequences for the health of the population of the sub-region - like price increasesand therefore decreasing their access to the drugs. In addition to this, ASINFAR argued that the decree limited the competition for national laboratories over the molecules that were already in technical status and of public domain.

The Colombian government, grounding its argument on the principle of "indispensable complement", ${ }^{61}$ argued that because Decision 486 of the Commission does not detail how to guarantee the protection of undisclosed information, by Decree 2085 Colombia is detailing the way to grant it. Colombia affirmed that the principal aim of Decree 2085 was to establish a proceeding for a sanitary registry of drugs which was not provided by Andean or Colombian legislation.

\footnotetext{
${ }^{59}$ Association of Colombian Pharmaceuticals (ASINFAR) v. Republic of Colombia (February 9, 2006), file number 114-AI-2004, online: Comunidad Andina - Documentos Oficiales - Procesos del Tribunal de Justicia <http://intranet.comunidadandina.org/IDocumentos/c_Newdocs.asp?GruDoc=11 > .

${ }^{60}$ Decision 486 - Intellectual Property Regime for the Andean Community, online: Sistema de Información sobre Comercio Exterior 〈http://www.sice.oas.org/Trade/Junac/decisiones/dec486s1.asp〉.

${ }^{61}$ See supra note 49.
} 
The Court declared the action sustained and found Colombia in breach of Andean law when it issued Decree 2085 to regulate diverse aspects of the information supplied to obtain the register for new chemical entities in the pharmaceutical sector. By granting periods of exclusivity with this Decree, which the Court declared proved, the Court found Colombia in breach of Andean regulations. Colombia was required to adopt appropriate measures to reestablish the Andean norms infringed.

Regarding public health and consumers of pharmaceuticals in developing countries like the members of the Andean Community, the Court reasoned that granting exclusive rights for certain periods of time might be in conflict with fundamental rights like health and life. This is because the consumption of drugs is related to their price. A monopoly price might make it impossible to access the drug and subject potential consumers to sickness and death. Regarding test data, to protect it for a determined time has the effect of unduly extending the monopoly of the patent, consequently postponing free competition in the market and increasing the difficulty of accessing the drug. The protection granted by the Decree is not compatible with the one established in the Andean legislation, nor with the limits of public health, nor with the process of integration.

This is the only decision issued by the Court on this case. There were no further decisions on its compliance or non-compliance before the Court. Nevertheless, after this decision, Colombia successfully promoted a reform to Decision 486 after which the Andean Commission issued Decision 632. ${ }^{62}$ The latter authorizes the use of periods of exclusivity for test data by members of the Andean Community. If the protection turns out to be harmful for national public health or food security, the members might eliminate or suspend this protection. ${ }^{63}$

\footnotetext{
62 Carlos M. Correa, "Nota para discusión: Jurisprudencia relevante sobre productos farmacéuticos en América Latina" in Seminario para jueces sobre tendencias recientes en materia de propiedad intelectual con particular énfasis en la industria farmacéutica organized by the International Centre for Trade and Sustainable Development, October 2009, online: ICTSD <http://ictsd.org/downloads/2009/10/correa_la_jurisprudence.pdf >.

63 According to Carlos Correa this reform was one of the main reasons for Venezuela's withdrawal from the Andean Community.
} 
The decisions of the Andean Court in the four cases above show the role assigned to human rights according to the core documents which created the Andean Community. The interpretation done by the Court of Justice of the Andean Community has clearly had a pro-human rights protection attitude. The decisions of the Court look more consistent than the cases from Mercosur. Nevertheless, this system also has its challenges, for example, in the Farmagra case against Peru in which Peru has still not complied with the Court's decision. It would seem from reading the decisions that human rights are being respected in the Andean Community and that they are a priority for its members. And they are, as was mentioned above; however, it is in looking at the aftermath of the cases where questions arise regarding the practical effectiveness of these mechanisms. It is not enough that human rights are included in the text of the agreements and can be argued to have high priority if their protection does not actually reach society.

Another issue to pay attention to is the contradictions that might be discerned among the judicial organs of the Andean Community. In the last case, on periods of exclusivity for test data, the Court ruled to disallow them on grounds of protection of human rights. Yet, later in time, Colombia pushed negotiations at the Andean Commission level and a new decision by the Commission was issued authorizing the members of the Andean Community to grant periods of exclusivity on test data. ${ }^{64}$ It is said that Colombia pushed for this decision as a way to address a fundamental issue that it was debating on a bilateral free trade agreement with the United States. This is the reason why Venezuela's renunciation of the Andean Community is linked with this decision, because Venezuela has opposed the FTAs that Colombia and Peru negotiated with the United States. If we look just at the decisions from the Court we could argue about how high its commitment is for protection of human rights and how successful the procedure was because there was no appeal on the issue. Nevertheless, there was no effective redress for society because the later decision from the Commission authorized the periods of exclusivity.

\footnotetext{
${ }^{64}$ Decision 632 of the Andean Commission - Clarification of the second paragraph of article 266 of Decision 486 of 2000 (6 April 2006), online: Sistema de Información Sobre Comercio Exterior <www.sice.oas.org/Trade/Junac/Decisiones/Dec632s.doc>.
} 


\section{E. What is in the future for the relationship between trade and human rights in the Americas?}

The experience of the three most important regional agreements in the Americas regarding human rights arguments in trade disputes shows significant differences on how they have been dealt with and on the status of the relationship between trade and human rights within these agreements. More importantly, this study takes us to reflect on the effectiveness of their approaches and the future possibilities to enhance the protection of human rights in the region. In NAFTA human rights have not been discussed in trade disputes at all. There are no specific provisions on the topic in its content except the side agreements on labour and the environment. However, these do not account for a full protection of human rights. In particular, the United States has been reluctant to submit to international multilateral human rights mechanisms, and it seems this will not change in the near future.

Meanwhile, in Mercosur and the Andean Community human rights protection is declared as a core principle to achieve their objectives. The review showed trade cases in which human rights arguments have been raised by the parties and addressed by the courts or tribunals when deciding on a dispute. In the case of Mercosur, the most noticeable detail is how the Permanent Tribunal of Revision has explicitly declared that the main objective of the union is trade liberalization and that all principles should yield to it. Unfortunately, in both cases presented, there have not been effective consequences to the decisions from the Tribunal. Argentina has refused to comply with the Tribunal's decisions. This attitude brings attention to how Mercosur members declare human rights protection as a core principle for the union but then it is better for them to accept the consequences of not complying with a decision from a Tribunal to which they agreed to its jurisdiction. In the second case of Mercosur, it should also be borne in mind that the human rights arguments opposed by Argentina could be seen as a justification for their inaction, which could have been used as a way to put pressure on Uruguay for the pulp mills conflict. Nevertheless, the important point is that the TPR reaffirmed its position on considering free movement as a commitment with higher priority. 
The experience of the Andean Community shows decisions more aligned with the declaration of human rights as a fundamental principle of the union. But we cannot look just at the decisions of the tribunal, we need to explore their aftermath to assess whether there was an effective change or redress for the issue at hand in each dispute. And it is in the aftermath, in reports from the media, or contradictory decisions from its organs, where we can assess the consequences that these decisions have had. And as shown above, not all of them have been positive for the protection of human rights.

The fact that NAFTA is a free trade agreement and Mercosur and the Andean Community are agreements aimed at regional integration highlights an issue to be addressed in this trade-human rights relationship. Does it mean that human rights should be addressed in conjunction with trade only when there is a further intention of the states to achieve integration? According to the opinions of scholars referred to in the outset, the answer would be in the negative. Then we have the question of whether human rights clauses should be included in free trade agreements or if the Systems of Preferences offered by the United States and the European Union to some states could be a better approach.

The European Union has offered the Generalized System of Preferences ${ }^{65}$ (GSP) since 1971, and more recently the Special Incentive Arrangement for Sustainable Development and Good Governance (GSP+), as a way to positively motivate developing countries to commit to democracy, human rights, and the rule of law by granting them trade benefits on the condition of subscribing and implementing fundamental international instruments on human rights. This can be contrasted with adopting a more punishing approach where human rights clauses are included in trade agreements. The idea of this contrast is that while a human rights clause punishes a country for not complying, a system of preferences rewards the country for its efforts in advancing the promotion of human rights, democracy, and the rule of law. GSP and GSP+ systems have been the object of

65 For details on the GSP and GSP+ see: European Commission, Trade online: European Commission <http://ec.europa.eu/trade/wider-agenda/development/generalised-system-of-preferences/>. 
various analyses. One done by Franz Ebert, ${ }^{66}$ recognizes the achievements that this system has brought for developing countries but also reflects on its shortcomings, in particular concerning substantive requirements. The author is certain that the benefits of this kind of human rights conditionality can be very positive for developing countries, but that it needs to be implemented in a credible manner.

In the Americas, many countries are part of these programs ${ }^{67}$ and some positive results can be observed in the achievements they have had. But the question remains open as to how to bring a country like the United States into compliance with the same terms that developing countries are held to. This would entail dealing with broader assumptions by which the U.S. is considered a model to be followed in topics of democracy, human rights, and the rule of law-an assumption we could question.

There is no questioning the importance of jointly addressing human rights and trade. Authors even suggest that it should be an obligation of trade to regulate consistently with human rights law. ${ }^{68}$ The main challenge remains the "how". Powell suggests that one of the most important steps is for the UN and regional human rights agencies to specify which human rights are most closely connected to trade so that they can be considered as trade's benchmarks. This suggestion poses a big challenge if we consider how hard it has been to reach international consensus on the understanding of the meaning of human rights for diverse countries and cultures; we cannot even say that we have reached that consensus. This step, to prioritize them in a certain order, would imply more challenges for the international community.

For the regional agreements studied in this paper, the future could bring better possibilities if, in the case of Mercosur and the Andean Community, its members concentrate on finding ways of making their systems more effective. They have the principles and are already committed to the protection of human rights. The challenge lies

\footnotetext{
${ }^{66}$ Franz Christian Ebert, "Between Political Goodwill and WTO-Law: Human Rights Conditionality in the Community's New Scheme of Generalised Tariff Preferences (GSP)" (2010) ZERP Working Paper Series 8/2009, online: SSRN <http://ssrn.com/abstract=1721678>.

${ }^{67}$ Examples of countries that benefit from GSP are: Bolivia, Colombia, Ecuador, Peru, Paraguay, and Venezuela.

${ }^{68}$ Powell, supra note 7.
} 
in making them work positively in the area of trade. It would be for the future to show if UNASUR would result in a more effective union in this regard. As for NAFTA, here is where I would pose the biggest question, whether it would be possible to include certain kind of human rights clauses that would commit the three parties at the same level. 